\title{
Physical Bean Quality of Arabica Coffee (Coffea Arabica) at High and Medium Altitude
}

\author{
Dwi Nugroho ${ }^{1 *}$, Panjisakti Basunanda ${ }^{22}$, and Suyadi $\mathrm{Mw}^{2)}$ \\ ${ }^{1}$ Indonesian Coffee and Cocoa Research Institute, J1. PB. Sudirman No. 90, Jember, Indonesia \\ ${ }^{2)}$ Faculty of Agriculture, Gadjah Mada University, Yogyakarta, Indonesia \\ *)Corresponding author: dwinugroho.iccri@gmail.com \\ Received: 15 October 2016/ Accepted: 27 November 2016
}

\begin{abstract}
Reducing productivity, outbreak of insects and diseases, and decreasing in physical and cup quality are major problems for Arabica coffee cultivation in medium altitude. The aim of this study was to investigate the effect of altitude on physical quality in eight genotypes of Arabica coffee. This research was conducted at two locations i.e. Andungsari Research Station-Bondowoso (1250 m asl. as high altitude) and Kalibendo Estate-Banyuwangi (700 m asl. as medium altitude). Randomized complete block design was used with three replications. Collected data consisted of outturn, weight of 100 beans, shape bean normality, apparent swelling, bulk density before and after roasting. Combined analysis on the physical quality traits of green bean showed genotype $\mathrm{x}$ altitude interactions on weight of 100 beans, percentage of normal beans and percentage of empty bean. Altitude significantly influenced coffee outturn. Decreasing in altitude from $1.250 \mathrm{~m}$ asl. to $700 \mathrm{~m}$ asl. caused declining in the outturn as much $32.9 \%$. BP $700 \mathrm{~A}, \mathrm{~K} 29, \mathrm{~K}$ 34 , K 79, and K 99 were genotypes that stable to produce normal bean and empty beans at high and medium altidute, while $\mathrm{K} 8$, K 130, and SIG were genotypes with high normal beans at high altitude but not stable. Genotype $\mathrm{x}$ altitude interaction did not occur for physical quality of other variables of outturn, bulk density before and after roasting, apparent swelling, percentage of round beans, percentage of elephant beans, and percentage of triage beans. Altitude showed significant effect on all of physical quality of bean variables.
\end{abstract}

Keywords: Coffea arabica, flavor, physical quality, altitude

\section{INTRODUCTION}

Increasing production of Arabica coffee can be achieved and expanding plantation area. Increasing the production by using intensification is considered to be more difficult, because Arabica coffee crops naturally produce low yield for one to two years after peak production, or known as biennial bearing phenomenon (Yahmadi, 1973). The increase of production can be achieved by expanding plantation land or using planting material which can adapt to specific-site condition and has a better flavor. Arabica coffee breeding program is not only designed to produce varieties which have high productivity and resistance to pests and some diseases, but also to produce a high quality which has a unique and pleasent flavor (Leroy et al., 2006). 
Arabica coffee can grow well in the highlands (> $1000 \mathrm{~m}$ above sea level). Arabica coffee extensification at the altitude of more than $1000 \mathrm{~m}$ asl. is relatively difficult, because it is not easy to find available farmland at these altitudes in Indonesia. Commodity competitors such as horticultural crops increasingly limit the availability of suitable land for Arabica coffee. Land-use extension is still largely available at medium-altitude (700-900 $\mathrm{m}$ asl.), the minimum height which is still considered to be appropriate for the cultivation of Arabica coffee (Hulupi, 2006). Arabica coffee cultivation at medium-altitude faces many problems, such as the attack of pests and diseases as well as decrease of flavor quality (Hulupi, 2006). It is also important to know the effects of farmland altitude on the physical appearance of the coffee produced.

Leroy et al. (2006) explained that there were four important characters of coffee which strongly influence coffee quality, namely bean water content, bean physical quality, flavor quality and health quality which were indicated by biochemical content affecting plant health. Physical quality, flavor quality and biochemical content are the three important characters which are affected by genetic properties of the plants, planting practice, environment and interaction between genotype and environment (Wintgens, 2004a). Meanwhile, bean water content is affected by post-harvest treatment process. Therefore, in order to improve the quality of coffee, the three components can be used as observation variables.

Bean physical quality has a very important role in the implementation of the postharvest technology to be used. The main criteria of bean physical quality are bean size and abnormal bean percentage such as elephant beans and pea berries (Eskes \& Leroy, 2004). Moreover, the bean physical quality, such as bean size, affects coffee price. Bean size has an important role in producing good roasted coffee because many consumers believe that bean size is positively correlated with the quality, although, in fact, larger-sized beans do not always produce a better flavor than smaller-sized ones (Wintgens, 2004a).

Information on physical quality of Arabica coffee grown in medium-altitude land and quality changes occurred in genotypes need to be tested in order to prepare the Arabica coffee breeding program which is adaptive to the medium-altitude land. This study will examine the physical quality of Arabica coffee grown in highlands and medium-altitude lands as well as quality changes as a result of different genotype and land altitude. Although it has been widely known that altitude has a great effect on coffee quality, only few scientific studies have documented the effects (Bertrand et al., 2006).

\section{MATERIALS AND METHODS}

The study was carried out during harvest season at two locations with different types of climate and altitudes, of Andungsari and Kalibendo Plantations. Andungsari Experimental Station at Indonesian Coffee and Cocoa Research Institute was located in highland of Bondowoso Regency at an altitude of $1250 \mathrm{~m}$ asl. and classified at C climate type according to Schmidt \& Ferguson classification (1951). Kalibendo Plantation was located in medium-altitude in Banyuwangi Regency at an altitude of $700 \mathrm{~m}$ above sea level and classified at B climate type according to Schmidt \& Ferguson.

Experimental design was completely randomized with three replications. Each replication consisted of eight Arabica coffee genotypes of superior varieties and promising lines (Table 1). BP 700 clone was F1 clonal hybrid selection number KB II/61/3 and their 
mother tree was introduction with accession of number C-1662-10-3. K8, K29, K34, K79, K99 and K130 which were genotypes constituting KOMASTI (Composite Andungsari 3) which had been released based on Decree of the Minister of Agriculture No. 200/Kpts/ SR.120/1/2013 dated 18 January, 2013. The genotypes were obtained from the results of the selection on 136 host trees at the population of F2-F4 'Catimor' generation which were introduced from coffee research centers of several countries (Hulupi et al., 2012). Sigararutang was good quality variety as a result of participative breeding in North Sumatera Province which was released as national-qualified variety based on Decree Minister of Agriculture in No.205/Kpts/ SR.120/4/2005 dated 12 April, 2005. There were 48 total number of test unit locations and each experimental unit consisted of 20 plants grown in two rows. Planting distance in row was $2 \mathrm{~m}$, while the between-row varied depending on contours.

Planting in Andungsari was conducted in February 2009, while planting in Kalibendo was conducted in December 2008. The cultivation in Andungsari Experimental Station had shade trees of Indigofera sp., while in Kalibendo used of productive shade plants (Macadamia integrifolia and Syzygium aromaticum). The coffee plants were grown according to the standard cultivation such as by giving inorganic fertilizers as recommended dosage in twice a year, while organic fertilizers were given once a year through planting holes. The plants were pruned using a two-stage single-stem system and pests were controlled using pesticides.

The ripe red coffee cherries were harvested manually. The maturation of the cherries from each genotype at each location did not occur at the same time, so the harvesting processes were rotated every 14 days in each location. The harvesting processes were conducted during three months between JuneAugust, until number of samples was considered sufficient. The cherries were put in small bags which were labeled with codes identifying the location, replication, and genotype.

The outer layer of fruit flesh was separated from the beans using depulper machine to avoid mixture of beans from different treatment. The coffee beans were then fermented for 12 hours. After the fermentation was completed, the beans were washed with clean water and dried until the water content reached 9.5-12\% (Wintgens, 2004a). The harvest and post-harvest processes were continued until the crop rotation was complete. Minimum number of samples for each experimental unit was $5 \mathrm{~kg}$. After the crop harvest was complete, coffee beans covered with husks which was commonly called or horn scull (HS) beans resulted from each rotation was collected in a bag coded by location, replication and genotype. The elephant beans were pounded to produce green beans. Finally, the green beans were used as the sample.

Table 1. Arabica coffee genotypes tested in this study

\begin{tabular}{lcl}
\hline Genotype & Code & \multicolumn{1}{c}{ Notes } \\
\hline BP 700A/BP 308 & BP 700A & Promising variety dwarf type selection no BP 700A \\
K 8 & K 8 & Genotype of composite varieties 'KOMASTI' \\
K 29 & K 29 & Genotype of composite varieties 'KOMASTI' \\
K 34 & K 34 & Genotype of composite varieties 'KOMASTI' \\
K 79 & K 79 & Genotype of composite varieties 'KOMASTI' \\
K 99 & K 99 & Genotype of composite varieties 'KOMASTI' \\
K 130 & K 130 & Genotype of composite varieties 'KOMASTI' \\
Sigararutang & SIG & Recommeded variety of participatory breeding in North Sumatera
\end{tabular}


Observations were conducted during harvest, post-harvest, and after the harvest rotation was completed, based on the observed variables. Observations on physical quality of beans were made before and after roasting process. The observed variables were out turn [(weight of green beans: weight of elephant beans) $\times 100 \%$, weight of 100 beans $(10-12 \%$ water content). The normal beans percentage was observed by cross-cutting 100 coffee beans in each tree, and observations were repeated three times, followed by calculating percentage of the normal beans. The rest of it were pea beans, polyembryonic beans, empty beans and elephant beans. Bulk density before-roasting $\left(\mathrm{g} \mathrm{mL}^{-1}\right)$ was calculated by measuring volume of $150 \mathrm{~g}$ coffee beans in a measuring cup. Bulk density after-roasting $\left(\mathrm{g} \mathrm{mL}^{-1}\right)$ was calculated by measuring volume of $150 \mathrm{~g}$ coffee beans in a measuring cup. Apparent swelling was calculated by dividing the volume of after-roasting with beforeroasting.

The physical quality of the coffee beans was analyzed using a combined variance analysis to determine the effect of genotype, environment and genotype $x$ environment interactions. According to Neter et al. (1996) the combined variance analysis models are:

$$
\begin{aligned}
& \mathrm{Y}_{\mathrm{ijk}}=\mu+\mathrm{L}_{\mathrm{i}}+\mathrm{B}_{\mathrm{k}(\mathrm{i})}+\mathrm{G}_{\mathrm{j}}+(\mathrm{LG})_{\mathrm{ij}}+\mathrm{E}_{\mathrm{ijk}} \\
& \text { i } \quad=1,2 \\
& \mathrm{j} \quad=1,2,3,4,5,6,7 \text { and } 8 \\
& \mathrm{k}=1,2,3 \\
& \mathrm{Y}_{\mathrm{j} \mathrm{k} \mathrm{k}}=\text { Direct variable from the treatment } \\
& \text { in location-i, genotype-j, and group-k } \\
& \mu \quad=\text { General mean } \\
& \mathrm{L}_{\mathrm{i}} \quad=\text { Effect of location- } \mathrm{i} \\
& B_{k(i)}=\text { Effect of group }-k \text { in location- } i \\
& \mathrm{G}_{\mathrm{j}} \quad=\text { Effect of genotype- } \mathrm{j} \\
& (L G)_{i j}=\text { Effect of interaction of genotype- } j \\
& \text { at location-i } \\
& \mathrm{E}_{\mathrm{j} \mathrm{k}}=\text { Experimental error in the location- } \mathrm{i} \text {, } \\
& \text { genotype-j and group-k }
\end{aligned}
$$

Variables which showed significant different results based on the combined analysis of variance were further analyzed using Tukey's HSD (honest significant difference) test at $\alpha=5 \%$.

\section{RESULTS AND DISCUSSION}

\section{Out Turn}

Table 2 showed that genotypes which were grown in the highlands showed higher out turn than medium-altitude, the difference was about $33 \%$. The highest out turn was Sigararutang (SIG) and the lowest yield was BP700A (Table 3).

This result was contradictive with Gaspari-Pezzopane et al. (2005) that bean out turn at $1280 \mathrm{~m}$ asl. decreased $4.4 \%$ than at $950 \mathrm{~m}$ asl. It was physiologically caused by warmer temperature at mediumaltitude which in turn affected cherries maturation rate so that they were not perfectly ripe (Guyot et al., 1996)

\section{Bean Weight}

Weight of 100 beans was a marker of the bean size, the heavier the weight of 100 beans, the larger the size of the beans. The results of the combined variance analysis showed that the size of the coffee beans was not only affected by the genotype but also by the environmental factors and their interaction. The highest weight of 100 beans was obtained from K 99 genotype when grown at the highlands, although the value was not significantly different with other genotypes. While in the medium-altitude lands, there was not any significant difference from the weight of 100 beans of all genotypes, except the BP 700A genotype which had the lowest weight (Table 4). 
Bean size plays an important role in coffee trade because larger size of coffee beans are more expensive, though the larger size does not always produce better flavor (Wintgens, 2004a). Genotypes grown in medium-altitude tended to have smaller beans and lower weight of 100 beans compared to genotypes grown in highlands. Weight of coffee beans varies from $100 \mathrm{mg}$ to more than $200 \mathrm{mg}$ (Clifford, 1985) and the weight of 100 Arabica coffee beans vary between 18-22 g (Wintgens, 2004b). The variance in the size of coffee beans is not only caused by the genetic factor but also related to environmental conditions, and the use of organic material in the cultural practices (Clifford, 1985; Wintgens, 2004c). This result was consistent with this results of those previous works that the weight of 100 beans was influenced by genotype, environment and interaction between genotype and environment.

\section{Bean Normality}

Wormer (1964) classified normality of coffee beans into two, namely normal and abnormal beans. Normal beans are formed

Table 2. Combined analysis on outturn, weight of 100 beans, percentage of normal beans, percentage of round beans, percentage of empty beans, percentage of elephant beans, and percentage of triage beans

\begin{tabular}{|c|c|c|c|c|c|c|c|c|}
\hline \multirow{3}{*}{ Source of variation } & \multirow{3}{*}{$\mathrm{df}$} & \multicolumn{7}{|c|}{ Physical quality } \\
\hline & & \multirow{2}{*}{ Outturn } & \multirow{2}{*}{$\begin{array}{l}\text { Weight of } \\
100 \text { bean }\end{array}$} & \multicolumn{5}{|c|}{ Percentage } \\
\hline & & & & $\begin{array}{c}\text { Normal } \\
\text { bean }\end{array}$ & $\begin{array}{c}\text { Round } \\
\text { bean }\end{array}$ & $\begin{array}{c}\text { Elephant } \\
\text { bean }\end{array}$ & $\begin{array}{c}\text { Triage } \\
\text { bean }\end{array}$ & $\begin{array}{c}\text { Empty } \\
\text { bean }\end{array}$ \\
\hline Altitude & 1 & $* *$ & $* *$ & $* *$ & $* *$ & $* *$ & $* *$ & $* *$ \\
\hline Block (Altitude) & 4 & $\mathrm{~ns}$ & $\mathrm{~ns}$ & $\mathrm{~ns}$ & $\mathrm{~ns}$ & $\mathrm{~ns}$ & $\mathrm{~ns}$ & $\mathrm{~ns}$ \\
\hline Genotype & 7 & $* *$ & $* *$ & ns & $\mathrm{ns}$ & $\mathrm{ns}$ & ns & ns \\
\hline Genotype $\times$ Altitude & 7 & ns & $* *$ & $* *$ & ns & $\mathrm{ns}$ & $\mathrm{ns}$ & $*$ \\
\hline Coefficient variation (\%) & 7.39 & 4.83 & 7.43 & 5.31 & 6.83 & 7.14 & 4.52 & \\
\hline \multicolumn{9}{|c|}{ Notes: Percentage of round bean, elephant bean, and empty bean variable was use transformation data $\sqrt{x+0.5}$} \\
\hline \multicolumn{9}{|c|}{ df $\quad: \quad$ degree of freedom } \\
\hline \multicolumn{9}{|c|}{$* *:$ high significant different at $\alpha=1 \%$ level } \\
\hline \multicolumn{9}{|c|}{$* \quad$ : significantly different at $\alpha=5 \%$ level } \\
\hline \multicolumn{9}{|c|}{ ns : non significantly different } \\
\hline
\end{tabular}

Table 3. Out turn value of eight genotypes of Arabica coffee at two different altitude

\begin{tabular}{llllllllll}
\hline \multirow{2}{*}{ Altitude } & \multicolumn{7}{c}{ Outturn (\%)/Genotype } \\
\cline { 2 - 8 } & BP 700A & K 8 & K 29 & K 34 & K 79 & K 99 & K 130 & SIG \\
\hline High & 14.8 & 17.0 & 17.44 & 17.2 & 17.4 & 17.2 & 16.5 & 19.1 & $17.1 \mathrm{p}$ \\
Medium & 11.0 & 10.6 & 12.05 & 11.1 & 11,5 & 12.1 & 10.7 & 12.5 & $11.5 \mathrm{q}$ \\
Mean & $13.3 \mathrm{~b}$ & $13.8 \mathrm{ab}$ & $14.75 \mathrm{ab}$ & $14.1 \mathrm{~b}$ & $14.4 \mathrm{ab}$ & $14.7 \mathrm{ab}$ & $13.6 \mathrm{~b}$ & $15.8 \mathrm{a}$ & - \\
Outturn change (\%) & -25.9 & -37.6 & -30.9 & -35.4 & -33.6 & -29.6 & -35.6 & -34.9 & -32.9 \\
\hline
\end{tabular}

Notes: Values followed by the same letter(s) in the same column and row are not significant different according to Honest Significant Different (HSD) at $\alpha=5 \% ;(-)=$ No Interaction; BP700A genotype at medium altitude using two replications only. Value of MSD (Minimum Significant Different) altitude $=0.6337$ MSD genotype $=2.0289$.

Table 4. Weight of 100 beans of eight genotype of Arabica at two altitudes

\begin{tabular}{|c|c|c|c|c|c|c|c|c|c|}
\hline \multirow{2}{*}{ Altitude } & \multicolumn{8}{|c|}{ Weight of 100 bean, g/Genotype } & \multirow{2}{*}{ Mean } \\
\hline & BP $700 \mathrm{~A}$ & K 8 & K 29 & K 34 & K 79 & K 99 & K 130 & SIG & \\
\hline High & $12,3 \mathrm{c}$ & $17,4 \mathrm{ab}$ & $16,8 \mathrm{ab}$ & $16,4 \mathrm{ab}$ & $17,2 \mathrm{ab}$ & $17,7 \mathrm{a}$ & $16,8 \mathrm{ab}$ & $15,3 \mathrm{~b}$ & 16,2 \\
\hline Medium & $13,2 \mathrm{q}$ & $15,5 \mathrm{p}$ & $15,2 \mathrm{pq}$ & $15,6 \mathrm{p}$ & $15,6 \mathrm{p}$ & $15,5 \mathrm{p}$ & $15,1 \mathrm{pq}$ & $16,0 \mathrm{p}$ & 15,2 \\
\hline Mean & 12,8 & 16,4 & 16,0 & 16,0 & 16,4 & 16,6 & 16,0 & 15,6 & + \\
\hline
\end{tabular}

Notes: Values followed by the same letter(s) in the same row are not significant different according to Honest Significant Different $(\mathrm{HSD})$ at $\alpha=5 \% ;(+)=$ Interaction; SIG genotype at medium altitude using two replications only. MSD of highaltitude $=2.34 ;$ MSD of medium altitude $=2.09$. 
from berries which have two pits, and the two beans in each pit fully develop into normal beans with similar shape and size. Abnormal beans consist of pea berries, empty beans, elephant beans and triage beans. According to Antunes-Filho \& Carvalho (1955), abnormalities in coffee beans were controlled by genetic factors and environmental factors. The results of the combined variance analysis of bean normality showed that genotype $x$ location interaction did occur for normal beans and empty beans, while it happened on pea beanss, elephant beans, and triage beans.

BP 700A, K 29, K 34, K 79 and K 99 were genotypes which relatively stable in producing normal beans at both high and medium-altitude lands. The results were indicated by not significant different values of normal beans percentage at both altitude. K 8, K 130, and SIG were genotypes which had high but less stable of the normal bean percentage as it only happened for those grown in the highlands. The normal percentage of bean grown in the medium-altitude decreased and showed significant different value from normal percentage of bean grown in the highlands (Table 5).

The main cause of the low normal bean percentage is the high percentage of empty beans and pea berries (Table $6 \&$ Table 7). Study on the effect of genotype $x$ environment interaction on bean normality was conducted by Mawardi \& Hulupi (1995). The results of the study showed that there is a significant effect of genotype $x$ environment interaction to all normality variables have been tested, which means normal and abnormal bean formation is not only influenced by genetic factor but also influenced by environment where the plants grown.

\section{Pea Berries}

Pea berry percentage of genotypes grown in the medium-altitude lands (12.2\%) was higher than those grown on the highlands $(12.2 \%$ vs $7.5 \%)$, and the percentage of empty beans in medium-altitude lands was higher than those grown in the highlands (19.1\% vs 11.10$)$. It was caused by humid climate (B type) with higher rains and rainy days in the medium-altitude lands. The failure of pollination process was occurred when the flower experiencing a receptive period, means the rain happened when the plants were flowering.

Pea berries can be caused by incomplete pollination process when environment does not support, or caused by genetic properties of the plants (Eskes \& Leroy, 2004). High rainfall can disrupt pollination process and causes formation of empty beans and pea berries. According to Ricketts et al. (2004), the provision of insect pollinators around coffee plants can reduce percentage of pea berries by $27 \%$. It is indicated that pea berries formation is strongly influenced by

Table 5. Percentage of normal bean eight genotype of Arabica coffee at two different altitute

\begin{tabular}{|c|c|c|c|c|c|c|c|c|c|}
\hline \multirow{2}{*}{ Altitude } & \multicolumn{8}{|c|}{ Percentage of normal bean, $\% /$ Genotype } & \multirow{2}{*}{ Mean } \\
\hline & BP 700A & K 8 & K 29 & K 34 & K 79 & K 99 & K 130 & SIG & \\
\hline High & 69.0 & $79.9 *$ & 78.6 & 79.2 & 74.2 & 76.1 & $77.7 *$ & $79.9 *$ & 76.8 \\
\hline Medium & 72.0 & $60.3 *$ & 68.3 & 59.3 & 68.2 & 62.9 & $55.9 *$ & $64.7 *$ & 63.9 \\
\hline Mean & 70.5 & 70.1 & 73.5 & 69.2 & 71.2 & 69.5 & 66.8 & 72.3 & + \\
\hline
\end{tabular}


Table 6. Percentage of round bean eight genotype of Arabica coffee at two different altitude

\begin{tabular}{|c|c|c|c|c|c|c|c|c|c|}
\hline \multirow{2}{*}{ Altitude } & \multicolumn{8}{|c|}{ Percentage of round bean, $\% /$ Genotype } & \multirow{2}{*}{ Mean } \\
\hline & BP 700A & K 8 & K 29 & K 34 & K 79 & K 99 & K 130 & SIG & \\
\hline High & 9.33 & 6.72 & 6.98 & 6.42 & 9.43 & 8.33 & 6.80 & 6.02 & $7.51 \mathrm{~b}$ \\
\hline Medium & 9.52 & 12.43 & 11.55 & 14.14 & 11.56 & 13.54 & 17.81 & 14.13 & $12.19 \mathrm{a}$ \\
\hline Mean & 9,424 & $9 ., 58$ & 9.26 & 10.28 & 10.49 & 10.94 & 12.31 & 10.08 & - \\
\hline
\end{tabular}

the environmental conditions and pollination success.

Percentage of pea berries show highly correlated with the percentage of empty beans, for each pea berry is paired with an empty bean. However, empty bean is not necessarily paired with pea berry. As a result, the percentage of empty beans is always greater than percentage of pea berries. Recommended high-qualified variety of Arabica coffee generally produces less than $10 \%$ of pea berries (Eskes \& Leroy, 2004). Genotypes tested in highland had pea berries percentage of less than $10 \%$, while percentage of pea berries of plants grown in medium-altitude land is fairly higher (62.3\%) (Table 6). Pea beans is considered to be a defect, but after a sorting process, there is still a chance of being marketed because of the unique character (Ricketts et al., 2004).

\section{Empty Bean}

Variance of the empty bean percentage showed significant interaction between genotype and location, but genetic effect was not significantly different (Table 2). Research conducted by Mawardi \& Hulupi (1995) also showed an effect of the interaction between genotype $\times$ location which caused variance in the empty bean percentage. These result was contrast with studies conducted by Eskes \& Leroy (1955) on zuriat 'Mundo Novo' which indicated a strong effect of genetic factor on the empty bean. This difference occured because the genotypes used in this study were selected according to the normality of beans. Therefore, the bean abnormality due to genetic differences was relatively low.

The results of further tests also showed that BP 700A, K 29, K 34, K 79 and K 99 were genotypes which had stable percentage of empty beans at both locations. The results were indicated by not significant difference of empty beans percentage. K 8, K 130 and GIS genotypes had a low percentage of empty beans when they were grown in the highlands but increased significantly when they were grown in the medium-altitude.

\section{Elephant Beans}

Results of combined analysis of variance on elephant bean percentage showed that it was affected significantly by differences of altitude (Table 2). Based on the results of the further tests, all genotypes grown in the highlands produced higher percentage of elephant beans than those grown in the medium-altitude (Table 8 ). The high value of variance coefficient of elephant beans was due to very low percentage, which sometimes reached zero, so that the combined analysis of variance was performed using data transformation. Elephant bean is formed when the bean pit has more than one ovule, which will form more than one bean in a parchment (Mawardi \& Hulupi, 1995). 


\section{Triage Beans}

Arabica coffee flowers can sometimes produce three ovules in one pit, which develop perfectly to form three beans (triage) in a fruit with smaller size than normal one (Mawardi \& Hulupi, 1995). According to Wormer (1964), formation of triage beans is caused by genetic aberrations. The percentage of the triage beans from the genotypes tested in this experiment was not significantly different. However, genotypes grown in highlands tend to produce higher triage beans than those grown in the medium-altitude land (Table 9).

The results of studies on the nature of bean normality indicate that it is affected by genetic factors, altitude and their interaction. In a marginal environmental condition, environmental factors (especially altitude) have the greatest influence on the formation of bean normality variance. According to Mawardi \& Hulupi (1995), a high percentage of abnormal beans will reduce the productivity and physical quality of the bean produced. Differences in the ability of each genotype to produce a normal or abnormal bean can be used as a reference for plant breeders to select eligible genotypes or qualified clones.

\section{Bulk Density}

The combined variance analysis of bulk density showed before-roasting that the median value of variance was caused by genotype and altitude factors (Table 10). Genotypes grown in the highlands had higher mean of bulk density $\left(0.72 \mathrm{~g} \mathrm{~mL}^{-1}\right)$ than the genotypes grown in medium-altitude lands $\left(0.65 \mathrm{~g} \mathrm{~mL}^{-1}\right)$. K $29\left(0.71 \mathrm{~g} \mathrm{~mL}^{-1}\right)$ was a genotype with the highest bulk density, while $\mathrm{K} 8\left(0.67 \mathrm{~g} \mathrm{~mL}^{-1}\right)$ was a genotype with the lowest bulk density (Table 11).

Bulk density describes the level of porosity and coffee bean density (Franca et al., 2005). According to Yusianto et al. (2005),

Table 7. Percentage of empty bean eight genotype of Arabica coffee at two different altitudes

\begin{tabular}{lccccccccc}
\hline \multirow{2}{*}{ Altitude } & \multicolumn{7}{c}{ Percentage of empty bean, \%/Genotype } \\
\cline { 2 - 9 } & BP 700A & K 8 & K 29 & K 34 & K 79 & K 99 & K 130 & SIG & Mean \\
\hline High & 15,80 & $8,53 *$ & 10,55 & 9,87 & 12,34 & 11,13 & $11,36 *$ & $9,20 *$ & 11,10 \\
Medium & 14,911 & $20,88 *$ & 16,43 & 22,51 & 16,52 & 18,90 & $23,57 *$ & $18,77 *$ & 19,06 \\
Mean & 15,35 & 14,70 & 13,49 & 16,19 & 14,43 & 15,01 & 17,47 & 13,98 & + \\
\hline Notes: & Values followed by (*) in the samecolumn are significant different between high altitude and medium altitude according \\
& to Honest Significant Different (HSD) at $\alpha=5 \% ;(+)=$ Interaction; BP700A genotype at medium altitude using two \\
& replications only. MSD BP700A = 6.49; SIG = 6.20; K99 = 15.08; K8 = 8.31; K79 = 10.21; K34 = 22.47; K29 = \\
& 13.76; K130 = 10.04.
\end{tabular}

Table 8. Percentage of elephant bean eight genotype of Arabica coffee at two different altitudes

\begin{tabular}{|c|c|c|c|c|c|c|c|c|c|}
\hline \multirow{2}{*}{ Altitude } & \multirow[b]{2}{*}{ BP 700A } & \multirow[b]{2}{*}{ K 8} & \multicolumn{6}{|c|}{ Percentage of elephant bean, $\% /$ Genotype } & \multirow{2}{*}{ Mean } \\
\hline & & & K 29 & K 34 & K 79 & K 99 & K 130 & SIG & \\
\hline High & 0,38 & 0,44 & 0,71 & 0,55 & 0,33 & 0,38 & 0,55 & 0,16 & $0,33 \mathrm{~b}$ \\
\hline Medium & 0,77 & 2,00 & 0,71 & 1,16 & 1,21 & 1,54 & 1,55 & 0,88 & $1,48 \mathrm{a}$ \\
\hline Mean & 0,57 & 1,22 & 0,71 & 0,85 & 0,77 & 0,96 & 1,05 & 0,52 & - \\
\hline
\end{tabular}

Notes: Values followed by the sameletter (s) in the same row are not significant differentaccording to Honest Significant Different (HSD) at $\alpha=5 \% ;(-)=$ No Interaction; BP700A genotype at high altitude using two replication only. MSD Altitude $=0.3491$. 
Table 9. Percentage of triage bean eight genotype of Arabica coffee at two different altitude

\begin{tabular}{|c|c|c|c|c|c|c|c|c|c|}
\hline \multirow{3}{*}{ Altitude } & \multicolumn{8}{|c|}{ Percentage of triage bean } & \multirow{3}{*}{ Mean } \\
\hline & \multicolumn{7}{|c|}{ Genotype } & \multirow[b]{2}{*}{ SIG } & \\
\hline & BP 700A & K8 & K29 & K34 & K79 & K99 & K130 & & \\
\hline High & 9.86 & 9.59 & 8.14 & 8.46 & 8.90 & 8.25 & 8.95 & 9.22 & $4.15 \mathrm{a}$ \\
\hline Medium & 2.80 & 4.37 & 3.02 & 2.91 & 2.53 & 3.14 & 1.21 & 1.54 & $2.69 \mathrm{~b}$ \\
\hline Mean & 4.17 & 4.40 & 3.08 & 3.45 & 3.13 & 3.59 & 2.41 & 3.15 & - \\
\hline
\end{tabular}

Table 10. Result of combined analysis on variable bulk density before and after roasting, and apparent swelling

\begin{tabular}{lcccc}
\hline \multirow{2}{*}{ Source of variation } & $\mathrm{df}$ & \multicolumn{2}{c}{ Bulk density } & \multirow{2}{*}{ Apparent swelling } \\
\cline { 3 - 5 } & & Before roasting & After roasting & $* *$ \\
Altitude & 1 & $* *$ & $* *$ & $\mathrm{~ns}$ \\
Block (Altitude) & 4 & $\mathrm{~ns}$ & $\mathrm{~ns}$ & $\mathrm{~ns}$ \\
Genotype & 7 & $* *$ & $\mathrm{~ns}$ & $\mathrm{~ns}$ \\
Genotype x Altitude & 7 & $\mathrm{~ns}$ & 8.88 & 4.93 \\
\hline Coefficient variation $(\%)$ & 2.20 & & \\
\hline Notes: $* *$ : high significantly different at $1 \%$ level & & \\
$*:$ significantly different at 5\% level & &
\end{tabular}

Table 11. Value of bulk density before roasting eight genotypes of Arabica coffee at two different altitudes

\begin{tabular}{lllllllllll}
\hline \multirow{2}{*}{ Altitude } & \multicolumn{9}{c}{ Bulk density before roasting, g.mL - $^{-1}$ Genotype } & Mean \\
\cline { 2 - 8 } & BP 700A & K 8 & K 29 & K 34 & K 79 & K 99 & K 130 & SIG & \\
\hline High & 0.72 & 0,72 & 0,73 & 0,72 & 0,72 & 0,72 & 0,72 & 0,71 & $0,72 \mathrm{a}$ \\
Medium & 0.62 & 0,64 & 0,68 & 0,64 & 0,66 & 0,62 & 0,66 & 0,68 & $0,65 \mathrm{~b}$ \\
Mean & $0.68 \mathrm{pq}$ & $0,67 \mathrm{q}$ & $0,71 \mathrm{p}$ & $0,68 \mathrm{pq}$ & $0,69 \mathrm{pq}$ & $0,67 \mathrm{q}$ & $0,69 \mathrm{pq}$ & $0,70 \mathrm{pq}$ & - \\
\hline
\end{tabular}

Notes: Values followed by the sameletter (s) in the same column and row are not significant different according to Honest Significant Different (HSD) at $\alpha=5 \% ;(+)=$ Interaction; BP700A genotype at medium altitude using two replications only. MSD Altitude $=0.0092$. MSD genotype $=0.0294$.

bulk density of raw coffee was higher than $0.65 \mathrm{~g} \mathrm{~mL}^{-1}$. Test results of the study on eight Arabica coffee genotypes grown on highlands had a mean of $0.72 \mathrm{~g} \mathrm{~mL}^{-1}$. wich was higher than that of genotypes grown in the mediumaltitude $\left(0.65 \mathrm{~g} \mathrm{~mL}^{-1}\right)$.

The combined analysis of the variance at bulk density after-roasting and apparent swelling showed that the variance of the median valueis caused by the altitude (Table 10). Genotype grown in the highlands had a higher bulk density after-roasting value $\left(0.42 \mathrm{~g} \mathrm{~mL}^{-1}\right)$ than those grown in the medium-altitude $\left(0.35 \mathrm{~g} \mathrm{~mL}^{-1}\right)$ ( Table 12). According to Yusianto (2003), the good and optimum roasting result provides about $0.35 \mathrm{~g} \mathrm{~mL}^{-1}$ bulk density.

\section{Apparent Swelling}

Apparent swelling value describes the increase of volume of coffee bean after it was roasted. Size and volume of bean increase after it is roasted as a result of cellulose structure softening process, and the bean pressure increases due to the release of pyrolysis products (Clarke, 1987; Rodrigues et al., 2003).

Apparent swelling value of genotype grown in the highland (1.55) was lower than the genotypes grown in the medium-altitude lands (1.64) (Table 13). It was caused by the significant different of coffee bean size at both locations, although the bulk density before-roasting of plants grown in the high- 
Table 12. Value of bulk density after roasting eight genotypes of Arabica coffee at two different altitudes

\begin{tabular}{lccccccccc}
\hline \multirow{2}{*}{ Altitude } & \multicolumn{7}{c}{ Bulk density after roasting, g.mL - $^{-1}$ Genotype } \\
\cline { 2 - 8 } & BP 700A & K 8 & K 29 & K 34 & K 79 & K 99 & K 130 & SIG & Mean \\
\hline High & 0.43 & 0.40 & 0.43 & 0.40 & 0.43 & 0.41 & 0.42 & 0.42 & $0.42 \mathrm{a}$ \\
Medium & 0.37 & 0.35 & 0.37 & 0.35 & 0.36 & 0.34 & 0.29 & 0.35 & $0.35 \mathrm{~b}$ \\
Mean & 0.41 & 0.37 & 0.40 & 0.38 & 0.39 & 0.38 & 0.35 & 0.39 & - \\
\hline Notes: & Values followed by the same letter(s) in the same column are not significant different according to Honest Significant \\
\\
Different (HSD) at $\alpha=5 \% ;(-)=$ No Interaction; SIG and BP 700A genotype at medium altitude using two replications \\
only. MSD of altitude $=0.0207$.
\end{tabular}

Table 13. Apparent swelling value of eight genotypes of Arabica coffee at two different altitudes

\begin{tabular}{|c|c|c|c|c|c|c|c|c|c|}
\hline \multirow{2}{*}{ Altitude } & \multicolumn{8}{|c|}{ Apparent swelling/Genotype } & \multirow{2}{*}{ Mean } \\
\hline & BP $700 \mathrm{~A}$ & K 8 & K 29 & K 34 & K 79 & K 99 & K 130 & SIG & \\
\hline High & 1.50 & 1,61 & 1,54 & 1,60 & 1,51 & 1,55 & 1,56 & 1,54 & $1,55 \mathrm{~b}$ \\
\hline Medium & 1,51 & 1,66 & 1,64 & 1,64 & 1,65 & 1,66 & 1,62 & 1,73 & $1,64 \mathrm{a}$ \\
\hline Mean & 1,50 & 1,63 & 1,59 & 1,62 & 1,58 & 1,60 & 1,59 & 1,61 & - \\
\hline
\end{tabular}

Notes: Values followed by the same letter(s) in the same row are not significant different according to Honest Significant Different (HSD) at $\alpha=5 \%$; (-) = No Interaction; SIG and BP 700A genotype at medium altitude using two replications only. MSD of altitude $=0.0477$.

land was higher. The difference caused higher porosity of coffee beans produced from medium-altitude land which in turn caused the bean swelled larger after it was roasted.

\section{CONCLUSION}

Altitude significantly affected all variables of physical quality of Arabica coffee beans. The effect of genotype $x$ location interaction occured for outturn, weight of 100 beans, percentage of normal beans, and percentage of empty beans. Genotypes planted on the medium-altitude resulted in low before and after roasting bulk density than that in the highlands. The altitude provided a significant effect on the coffee outturn, lower yield in the lower altitude by $33 \%$. Genotypes of BP 700A, K 29, K 34, K 79 and K 99 were relatively stable in producing normal beans in both altitude. While K 8, K 130 and GIS were genotypes which had higher but less stable normal bean percentage because it only happened when they were grown in the highlands.

\section{REFFERENCES}

Antunes-Filho, H. \& A. Carvalho (1955). Melhoramento do cafeeiro: VII-ocorrência de lojas vazias em frutos de café "Mundo Novo." Bragantia. 13, 165-179.

Bertrand, B.; P. Vaast; E. Alpizar; H. Etienne; F. Davrieux \& P. Charmetant (2006). Comparison of bean biochemical composition and beverage quality of Arabica hybrids involving SudaneseEthiopian origins with traditional varieties at various elevations in Central America. Tree Physiology, 26, 1239-1248.

Clarke, R.J. (1987). Grading, storage, pre-treatments and blending. p. 321. In: R.J. Clarke \& R. Macrae (Eds.). Coffee Volume 2: Technology. Elsevier Science Publishers Ltd.

Clifford, M.N. (1985). Chemical and physical aspects of green coffee and coffee products. p. 457. In: Clifford, M.N. \& K.C.W. (Eds.). Coffee: Botany, Biochemistry and Production of Beans and Beverage. The AVI Publishing Company.

Eskes, A.B. \& T. Leroy (2004). Cofee selection and breeding. In: Wintgens, J.N. (Ed.), Coffee: Growing, Processing, Sustain- 
able Production. WILEY-VCH Verlag $\mathrm{GmbH} \&$ Co. KGaA, Weinheim.

Franca, A.S.; J.C.F. Mendonça \& S.D. Oliveira (2005). Composition of green and roasted coffees of different cup qualities. $L W T$ Food Science Technology, 38, 709-715.

Gaspari-Pezzopane; C. De; H.P. Medina Filho; R. Bordignon; W.J. Siqueira; L.A. Ambrósio \& P. Mazzafera (2005). Influências ambientais no rendimento intrínseco do café. Bragantia, 64, 39-50.

Guyot, B.; D. Gueule; J.C. Manez; J.J. Perriot; J. Giron \& L. Villain (1996). Influence de l'altitude et de l'ombrage sur la qualité des cafés Arabica. Plant Rech. Dévelop. 3, 272-283.

Hulupi, R. (2006). Kajian Genetika Ketahanan Kopi Arabika Terhadap Nematoda Penggali Akar (Radopholus similis Cobb). Disertasi, Universitas Gadjah Mada. Yogyakarta.

Leroy, T.; F. Ribeyre; B. Bertrand; P. Charmetant; M. Dufour; C. Montagnon \& D. Pot (2006). Genetics of coffee quality. Brazilian Journal of Plant Physiology, 18, 229-242.

Mawardi, S. \& R. Hulupi (1995). Genotype by environment interaction of bean characteristics in Arabica coffee. Proceedings, $16^{\text {th }}$ ASIC International Conference on Coffee Science, Kyoto, Japan. p. 416.

Neter, J.; M.H. Kutner; C.J. Nachtsheim \& W. Wasserman (1996). Applied linear statistical models. In: Regression. Analysis of Variance and Experimental Designs. Irwin Chicago.

Ricketts, T.H.; G.C. Daily; P.R. Ehrlich \& C.D. Michener (2004). Economic value of tropical forest to coffee production. Proceeding of Natural and Academy of Sciences. 101, 12579-12582.
Rodrigues, M.a.a.; M.L. a. Borges; A.S. Franca; L.S. Oliveira \& P.C. Corrêa (2003). Evaluation of physical properties of coffee during roasting. E-journal-CIGR V(03004). 1-12.

Schmidt, F.H. \& J.H.A. Ferguson (1951). Rainfall Types Based on Wet and Dry Period Ratios for Indonesia with Western New Guinea. Verhandeli. Kementerian Perhubungan Djawatan Meteorologi dan Geofisika, Jakarta.

Wintgens, J.N. (2004a). Coffee bean quality assessment. p. 976. In: Wintgens, J.N. (Ed.), Coffee: Growing, Processing, Sustainable Production. WILEY-VCH Verlag GmbH \& Co. KGaA.

Wintgens, J.N. (2004b). Factors influencing the quality of green coffee. p. 976. In: Wintgens, J.C. (Ed.), Coffee: Growing, Processing, Sustuinable Production. WILEY-VCH Verlag GmbH \& Co. KGaA, Weinheim.

Wintgens, J.N. (2004c). The coffee plant. p. 976. In: Wintgens, J.N. (Ed.), Coffee: Growing, Processing, Sustuinable Production. WILEY-VCH Verlag GmbH \& Co. $\mathrm{KGaA}$, Weinheim.

Wormer, T.M. (1964). Normal and abnormal development of coffee berries. Kenya Coffee, 29, 91-106.

Yahmadi, M. (1973). Pengaruh kemarau panjang terhadap tanaman kopi. Menara Perkebunan. 41, 235-240.

Yusianto (2003). Karakter fisik dan cita rasa kopi hasil penyangraian sistem pemanasan langsung. Pelita Perkebunan, 19, 152-170.

Yusianto; R. Hulupi; S. Mawardi \& C. Ismayadi (2005). Sifat fisiko-kimia dan cita rasa beberapa varietas kopi Arabika. Pelita Perkebunan, L, 200-222.

$$
* * 0 * *
$$

